\title{
EXAMINATION OF PHYTOCHEMICAL CONSTITUENTS - USING SEED EXTRACT OF MADHUCA LONGIFOLIA
}

\author{
MANIKANDAN D*, PARVEEN S, PERIASAMY PA \\ Department of Chemistry, Dr. Mahalingam College of Engineering and Technology, Pollachi, Tamil Nadu, India. \\ Email: manikandandhayalan88@gmail.com
}

Received: 27 February 2020, Revised and Accepted: 16 April 2020

\begin{abstract}
Objective: Our main scope and objective are to prepare seed extract of Madhuca longifolia, to characterize them using phytochemical activity studies, and to study the presence of so many bioactive substances established phytochemical activity and anti-foot ulcer treatment.

Methods: Weighed $75 \mathrm{~g}$ of plant sample (without preliminary drying) accurately (precisely weighed to within $0.10 \mathrm{~g}$ ) in a tarred evaporating dish. Care was taken so that no substantial amount of moisture is lost during preparation and that was representative of the official sample and the sample has been made to screening to following studies such as physicochemical constants, determination of moisture content, evaluation of pH of aqueous solution, evaluation of total ash, evaluation of acid-insoluble ash, evaluation of extractive values, evaluation of water-soluble extractive, evaluation of alcohol-soluble extractive, and preliminary phytochemical screening phytochemical profile of M. longifolia seed.
\end{abstract}

Results: The presence of so many bioactive substances established phytochemical activity and anti-foot ulcer treatment using M. longifolia seed which supports the traditional tribal medicinal consumption of the plant.

Conclusion: The quality of the plant can be estimated by determining the physical parameters. These investigations are of great importance for carrying out the revalidation and it was accomplished from the phytochemical study that the solvent extract contains flavonoid, carbohydrate, saponin, tannin, glycoside, protein, alkaloid, and amino acid which are responsible for various pharmacological actions and promotes that biological study is required to explore their potential therapeutic activities.

Keywords: Phytochemicals, Madhuca longifolia, Iluppai, Seed, Tribal and medicinal plants.

(C) 2020 The Authors. Published by Innovare Academic Sciences Pvt Ltd. This is an open access article under the CC BY license (http://creativecommons. org/licenses/by/4. 0/) DOI: http://dx.doi.org/10.22159/ajpcr.2020.v13i6.37113

\section{INTRODUCTION}

Madhuca longifolia belongs to the family Sapotaceae and is an Indian tropical tree found largely in South Indian plains and forests. It is commonly known as iluppai (Tamil word) which means honey. It is also known as Indian butter tree. Iluppai is a deciduous and mediumsized tree found in India, Nepal, and Sri Lanka [1,2], all the parts of iluppai possess many medicinal qualities. Seed - antiulcer, wound healing, refrigerant, aphrodisiac, and tonic, and leaf - anthelmintic, emollient, and rheumatism. Flower - refrigerant, liquor, increase milk production in woman, diuresis, antihelmenthic, and hepatoprotective. Bark - tonsillitis, stomachache, and anti-venom in snake poisoning. Oil - laxative, hemorrhoids, and piles [3]. It is composed of various phytoconstituents which include flavonoids, triterpenoids, glycosides, saponins, and steroids [4]. The trees of $M$. longifolia seed are represented in Fig. 1 Taxonomical classification is shown in Table $1[5,6]$.

The seeds of $M$. longifolia (Iluppai) are fed on by the moth Antheraea paphia which produces tassar silk (tussah) a form of wild silk of commercial importance in India. Oil extracted from its seeds is used for the treatment of foot ulcer, care of the skin, and manufacturing of soap and detergents and also used as vegetable butter. The oil is also used as a fuel oil.

\section{METHODS}

Collection of plant material: The plant seeds of $M$. longifolia (iluppai) were collected from Dr. Mahalingam College of Engineering and Technology, Campus Pollachi, Coimbatore District, Tamil Nadu, India. The plant was identified by Dr. U. Mani, Biotechnologist, and CSIRCentral Leather Research Institute, Adayar, Chennai.

\section{Chemical analysis}

Physicochemical constants determination of moisture content

Weighed $75 \mathrm{~g}$ of plant sample (without preliminary drying) accurately (precisely weighed to within $0.10 \mathrm{~g}$ ) in a tarred evaporating dish. Care was taken so that no substantial amount of moisture is lost during preparation and that was representative of the official sample. The weighed sample of the plant was placed in the tarred evaporating dish, dried at $110^{\circ} \mathrm{C}$ for $3 \mathrm{~h}$, and weighed. The drying and weighing were nonstop at $1 \mathrm{~h}$ period until distinction between two consecutive weighing almost corresponds and distinction was not more than $0.25 \%$. When unvarying weight was reached, the material was cooled for $1 \mathrm{~h}$ in a desiccators and the percentage of moisture content was calculated.

\section{Evaluation of $p H$ of aqueous solution}

The powdered materials ( $90 \mu \mathrm{m}$ mesh) were floating in glass distilled water. After $1.5 \mathrm{~h}$, clean and the clear solution was calculated for $\mathrm{pH}$.

\section{Evaluation of total ash}

Incinerated concerning $6 \mathrm{~g}$ of precisely weighed plant sample in a tarred silica dish at temperature not exceeding $650^{\circ} \mathrm{C}$ in anticipation of free from carbon and weighed. premeditated the proportion of ash with reference to the air-dried plant sample.

\section{Evaluation of acid-insoluble ash}

Boiled the ash obtained from total ash for $10 \mathrm{~min}$ with $35 \mathrm{ml}$ of dilute hydrochloric acid. Collected the insoluble matter in an ash less filter paper, washed with hot water, and ignited to constant weight. Calculated the proportion of ash with reference to the air-dried plant sample. The results are shown in Table 2 . 
Table 1: Taxonomical classification

\begin{tabular}{ll}
\hline Kingdom & Plantae \\
\hline Division & Magnoliophyta \\
Class & Magnoliopsida \\
Order & Ericales \\
Family & Sapotaceae \\
Genus & Madhuca \\
Species & Longifolia \\
\hline
\end{tabular}

Table 2: Physicochemical analysis of Madhuca longifolia

\begin{tabular}{lll}
\hline S. No. & Parameters & Value $\% \mathbf{W} / \mathbf{W}$ \\
\hline 1. & Colour & Brown coloured fine powder \\
2. & pH & 6.83 \\
3. & Loss on drying & 6.7605 \\
4. & Total ash content & 12.1912 \\
5. & Acid insoluble ash & 0.6742 \\
\hline
\end{tabular}

Table 3: Extractive values of Madhuca longifolia

\begin{tabular}{lll}
\hline S. No. & Parameters & Extractive values $(\%) \mathbf{W} / \mathbf{W}$ \\
\hline 1. & Hexane & 0.5186 \\
2 & Ethyl acetate & 0.8931 \\
3. & Methanol & 65.57 \\
4. & Aqueous & 87.25 \\
\hline
\end{tabular}

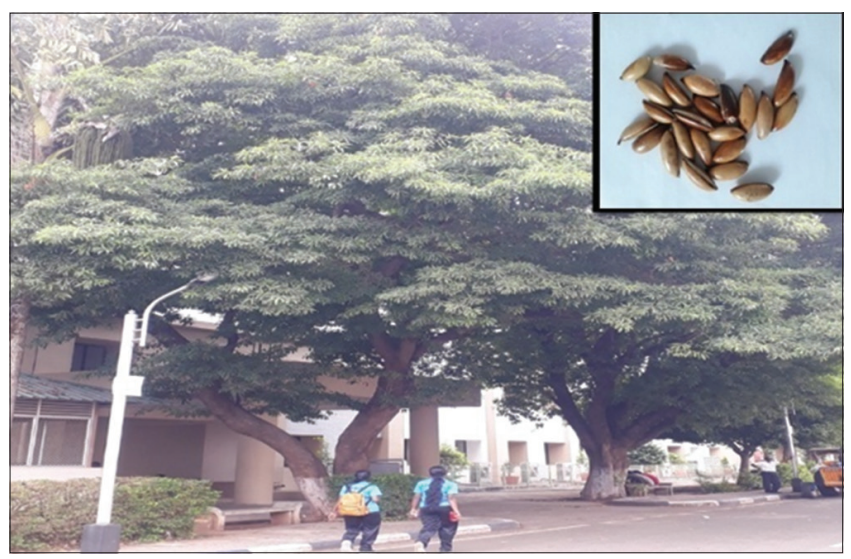

Fig. 1: The tree of Madhuca longifolia seed are represented

Evaluation of extractive values

Rightfully weighed quantity of the air dried, trampled plant sample was transfer to an extraction thimble, extracted with a mixture of solvents in the order of increasing polarity using Soxhlet extraction apparatus (for $8 \mathrm{~h}$ ). Filtered the extract quantitatively into a tarred evaporating dish and evaporated off the solvent on a water bath. The residue was dried at $110^{\circ} \mathrm{C}$ to constant weight. Particular extractive values reminiscent of water-soluble extractive and alcohol-soluble extractive value were determined as per standard procedure mentioned in the WHO Library [3]. The results are shown in Table 3.

\section{Evaluation of water-soluble extractive}

A $5 \mathrm{~g}$ of the air-dried plant sample was macerated with $100 \mathrm{ml}$ of water in a closed flask for $24 \mathrm{~h}$, frequently shaken during the first $6 \mathrm{~h}$ and allowed to stand for $18 \mathrm{~h}$. Filtered and evaporated $25 \mathrm{ml}$ of remains to dryness in tarred flat-bottomed China dish and dried at $105^{\circ} \mathrm{C}$ until constant weight is added. Premeditated the percentage of water-soluble extractive with reference to the air-dried plant sample.
Table 4: The preliminary phytochemical analyses of Madhuca longifolia extracts

\begin{tabular}{lllll}
\hline $\begin{array}{l}\text { Phytochemical } \\
\text { compounds }\end{array}$ & \multicolumn{4}{l}{ Cold percolation method } \\
\cline { 2 - 5 } & $\begin{array}{l}\text { Methanol } \\
\text { extraction }\end{array}$ & $\begin{array}{l}\text { Aqueous } \\
\text { extraction }\end{array}$ & $\begin{array}{l}\text { Hexane } \\
\text { extraction }\end{array}$ & $\begin{array}{l}\text { Ethyl } \\
\text { acetate } \\
\text { extraction }\end{array}$ \\
\hline Flavonoid & + & + & + & + \\
Carbohydrate & + & + & + & + \\
Saponin & - & - & - & - \\
Tannin & + & + & - & + \\
Glycoside & + & + & - & - \\
Protein & + & + & - & + \\
Alkaloid & + & - & + & + \\
Amino acid & + & + & + & + \\
\hline +: Present, $-:$ Absent & & & &
\end{tabular}

Evaluation of alcohol-soluble extractive

A $10 \mathrm{~g}$ of the air-dried plant sample was macerated with $200 \mathrm{ml}$ of alcohol in a closed flask for $48 \mathrm{~h}$, frequently shaken during the first $12 \mathrm{~h}$ and was allowed to stand for $18 \mathrm{~h}$. Rapidly filtered taking safety measures against loss of solvents. Evaporated $35 \mathrm{ml}$ of filtrate to dryness in a tarred flat-bottomed China dish and dried at $105^{\circ} \mathrm{C}$ until constant weight is added. Premeditated the percentage of alcoholsoluble extractive with reference to the air-dried plant sample.

\section{Preliminary phytochemical screening}

Newly prepared a variety of extracts of seed were analysis for the occurrence of phytochemical constituents using reported methods [7-9].

\section{RESULTS AND DISCUSSION}

Moisture content of drugs could be at bare minimum level to detect the growth of bacteria, yeast, or fungi during storage [10]. Ash values used to wrap up quality and purity of crude drug. It indicates the presence of various impurities such as silicate, carbonate, and oxalate $[11,12]$. In addition, the total ash of a crude drug also reflects the care taken in drug perpetuation, and the purity of crude and the prepared drug [13]. Acid-insoluble ash reflects the calcium oxalate content of the drug. In the current examination, considerable amount of total ash was noticed in seed, findings can be employed as quality parameter to evaluate $M$. longifolia. The vigorous chemical constituents may be soluble in different semi-polar, polar, and non-polar solvents [13]. Methanol and water showed highest extractive values, and both are able to extract most of phytoconstituents from the seed. Water decoction is a conventional method for preparation of drugs from the therapeutic plant [14]. The extractive values are valuable to assess the chemical constituent's current in the crude drug and also help in the estimation of specific constituents soluble in a particular solvent. The beginning phytochemical screening with the range of qualitative chemical tests naked the presence of various phytoconstituents such as carbohydrate, flavonoids, protein, tannins, and saponins. The results are shown in Table 4. The current investigate plants contained steroidal compounds. It should be noted that steroidal compounds are of importance and significance in pharmacy due to their relationship with such compounds as sex hormones [15]. The herb also contains saponins which are used to stop bleeding and in treating wounds and foot ulcers as it helps in red blood cell coagulation [16].

\section{CONCLUSION}

The current research is related to pharmacognostical, physical constants, and preliminary phytochemical screening of $M$. longifolia seeds provided useful information about its correct identity and evaluation. These parameters are required for the recognition of drugs and examination of the bioactive constituent in therapeutic herbs. The existence of a variety of chemical constituents in M. longifolia may be 
a prospective cause of cure of various disorders. The quality of the plant can be estimated by determining the physical parameters. These investigations are of great importance for carrying out the revalidation and it was accomplished from the phytochemical study that the solvent extract contains flavonoid, carbohydrate, saponin, tannin, glycoside, protein, alkaloid, and amino acid which are responsible for various pharmacological actions [17-20].

\section{ACKNOWLEDGMENTS/FUNDING}

The author is grateful to the Department of Chemistry, Dr. Mahalingam College of Engineering and Technology for infrastructure support.

\section{AUTHORS' CONTRIBUTIONS}

Dr. P. A. Periasamy and Dr. S. Parveen conceptualized the research idea, performed literature search, phytochemical analysis part of this work, reviewed the manuscript, and edited.

\section{CONFLICTS OF INTEREST}

The author declares that there are no conflicts of interest.

\section{REFERENCES}

1. Rout S, Rath B, Bhattamisra SK, Kumar A, Rath S. Neuroprotective effect of methanolic extract of Sargassum wightii on haloperidol induced catalepsy and tardive dyskinesia in albino rats. Int J Pharm Pharm Sci 2020;12:1-6.

2. Dhayalan M, Denison MI, Jegadeeshwari AL, Krishnan K, Gandhi NN. In vitro antioxidant, antimicrobial, cytotoxic potential of gold and silver nanoparticles prepared using Embelia ribes. Nat Prod Res 2017;31:465-8.

3. Evanjaline M, Mohan VR. Determination of bioactive components of Caralluma umbellata haw. (Apocynaceae) by gas chromatography and mass spectroscopy analysis. Asian J Pharm Clin Res 2018;11:194-9.

4. Vorobyova O, Grubova E, Belyaeva K, Solovyeva A, Plotnikova N, Deryabina $\mathrm{O}$, et al. Antioxidant, metabolic and antitumor activity of triterpenoids combination with cytostatics. Int $\mathrm{J}$ Pharm Pharm Sci 2020;12:49-56.

5. Akinmoladun AC, Ibukun EO, Afor E, Obuotor EM, Farombi EO. Phytochemical constituent and antioxidant activity of extract from the leaves of Ocimum gratissimum. Sci Res Essay 2007;2:163-6.

6. Rasika DB, Mahendra AG. Pharmacognostic and phytochemical investigation of Ailanthus excelsa roxb. bark. Asian J Pharm Clin Res 2020;13:74-8.
7. Manikandan D, Prakash DG, Gandhi NN. A rapid and green route to synthesis of silver nanoparticles from Plectranthus barbatus (Coleus forskohlii) root extract for antimicrobial activity. Int J Chem Tech Res 2014;6:4391-6.

8. Saluja M, Sangameswaran B, Hura IS, Sharma A, Gupta SK, Chaturvedi M. In vitro cytotoxic activity of leaves of Madhuca longifolia against ehrlich ascites carcinoma (EAC) cell lines. Int J Drug Discov Herb Res 2011;1:55-7.

9. Anonymous. Shodhganga. In: The Wealth of India: Raw Materials. New Delhi: India Council for Scientific and Industrial Research; 1976. p. 81-7.

10. Manikandan D, Denison MI, Manikandan A, Gandhi NN, Kathiravan K, Baykal A. Biogenic synthesis, characterization of gold and silver nanoparticles from Coleus forskohlii and their clinical importance. J Photochem Photobiol B 2018;183:251-7.

11. Yi-Zeng L, Peishan X, Kelvin C. Quality control of herbal medicines. J Chromatogr B Analyt Technol Biomed Life Sci 2004;812:53-70.

12. Manikandan D, Prakash DG, Arun J, Gandhi NN, Mani U, Kathiravan K. Antibacterial and anticancer activities of silver nanoparticles biosynthesized using Embelia ribes Burm.f. berries extract. Indian J Exp Biol 2019;57:175-80.

13. Deependra S. Anshita G, Rashmi S, Kumar JG. Pharmacognostical, phytochemical and physiochemical findings over the root extract of Hibiscus rosa sinesis [Malvacae]. J Nat Prod Plant Resour 2011;1:73-9.

14. Manikandan D, Jegadeeshwari LA, Gandhi NN. Biological activity sources from traditionally usedtribe and herbal plants material. Asian J Pharm Clin Res 2015;8:11-2.

15. Okwu DE. Evaluation of chemical composition of indigenous species and flavouring agents. Global J Pure Appl Sci 2001;7:455-9.

16. Santhi R, Alagesaboopathi C, Pandian MR. Antibacterial activity of Andrographis jineata Nees and Andrographis echioides Nees of the Shevaroy Hills of Salem District, Tamil Nadu. Adv Plant Sci 2006; 19:371-5.

17. Gogoi N, Bhuyan B, Deka T. Pharmacognostic standardization, preliminary phytochemical screening and TLC fingerprinting of the bark of Cascabela thevetia L. Int J Pharm Pharm Sci 2019;11:125-30.

18. Manikandan D, Kumar ST, Gandhi NN. Efficacy of biosynthesized silver nanoparticles as antimicrobial agent against Staphylococcus aureus and Escherichia coli by using Plectranthus barbatus (Coleus forskohlii) aqueous root extract. Res J Chem Environ 2014;18:1-5.

19. Ahmed FA, El-Bassossy TA. Active constituents and biological activity of methanolic extract of Forsskaolea viridis aerial parts. Asian J Pharm Clin Res 2020;13:40-6.

20. Naik R, Harisha CR, Acharya R. A comparative pharmacognostical evaluation of three botanical source plants of Jivanti. Int J Pharm Pharm Sci 2018;10:61-6. 